\title{
Optimization of genomic DNA extraction protocol for black wattle
}

\section{Otimização de protocolo de extração de DNA genômico para acácia-negra}

\author{
Yasmin Imparato Maximo \\ Universidade Federal do Paraná \\ E-mail: yasminimparato@gmail.com \\ OrcID: https://orcid.org/0000-0002-5396-9611
}

Angela Ikeda

Universidade Federal do Paraná

E-mail: aikeda@ufpr.br

OrcID: https://orcid.org/0000-0003-4647-2882

Paulo César Flôres Júnior

Universidade Federal do Paraná

E-mail: paulocesarfloresjunior@gmail.com

OrcID: https://orcid.org/0000-0002-0415-407X

Giovana Bomfim de Alcantara

Universidade Federal do Paraná

E-mail: giobomfim@ufpr.br

OrclD: https://orcid.org/0000-0001-5578-5843

Antonio Higa

Universidade Federal do Paraná

E-mail: higa@ufpr.br

OrclD: https://orcid.org/0000-0001-8486-0611

\begin{abstract}
As the integration of classic techniques and molecular genetics analysis is a current trend in forest tree improvement, a protocol for DNA extraction adapted for the study of each species is necessary. The objective of this study was to determine the effect of different adaptations in the CTAB protocol of genomic DNA extraction for black wattle. The following components were tested after the organic extraction phase: chloroform, phenol formaldehyde, and proteinase K. Also, the effects of applying RNase after the precipitation and cleaning phase were analyzed. The efficiency of these treatments was evaluated on fresh leaflets samples, as well as on samples refrigerated for seven days. The authors observed that all treatments enabled the successful genomic DNA extraction using the CTAB protocol. Moreover, storage did not affect the DNA integrity; adding RNase, however, resulted in an enhanced extracted DNA. Therefore, the use of chloroform and RNase according to the CTAB protocol on both fresh and refrigerated samples is suggested.
\end{abstract}

Keywords: Acacia mearnsii, CTAB, nucleic acids, RNase 
Resumo: Considerando-se que a atual tendência do melhoramento florestal é a integração das técnicas clássicas com as de análise genética molecular, faz-se necessária a obtenção de protocolos de extração de DNA genômico ajustados a cada espécie estudada. O objetivo do trabalho foi determinar o efeito de diferentes adaptações no protocolo de extração de DNA genômico CTAB para acácia-negra. Foram testados diferentes componentes na fase de extração orgânica: clorofórmio, fenol e proteinase $K$, além da aplicação de RNase após a fase de precipitação e limpeza do DNA. Também, foi investigada a eficiência destes tratamentos em amostras de folíolos frescas ou armazenadas em baixa temperatura durante sete dias. Foi verificada a presença de DNA de todas as amostras submetidas à extração pelo protocolo de CTAB com os diferentes tratamentos. O tempo de armazenamento das amostras não influenciou na integridade do DNA, entretanto, foi possível observar que a adição de RNase melhorou a qualidade do DNA extraído. Deste modo, sugere-se a utilização do protocolo CTAB com uso de clorofórmio e RNase, com amostras frescas ou armazenadas em baixas temperaturas.

Palavras-chave: Acacia mearnsii, ácidos nucleicos, CTAB, RNase

Data de recebimento: $28 / 12 / 2018$

Data de aprovação: 04/07/2019

DOI: https://doi.org/10.30612/agrarian.v13i49.9190

\section{Introduction}

Acacia is the fourth most common genus of trees in Brazil and it has a considerable economic impact in the South of the country (Ibá, 2016). The black wattle (Acacia mearnsii De Wildeman) is commercially cultivated in Rio Grande do Sul, a southern Brazilian state, where it provides significant economic returns due to the tannin present in its bark. The tannin is used in leather tanning and flocculant production, which is applied in water treatment. Currently, due to the compound present in its bark, the black wattle has an excellent yield and quality in tannin extraction, and the species is considered the primary vegetal source of tannin in the world (Ageflor, 2017). Therefore, the black wattle is socioeconomically valuable and the propagation of superior genotypes to increase productivity is in the interest of genetic improvement programs.

Genetic improvement for most forest tree species, is mainly performed by inbreeding techniques and artificial selection, in order to track superior genotypes. Although there are morphological descriptors to identify different clones of black wattle, genetic distinction by molecular markers is a vital tool to differentiate cultivated variety. In Brazil, the Serviço Nacional de Proteção de Cultivares (National Service of Cultivated Variety Protection) has not officially established minimum descriptors to differentiate, categorize and protect black wattle cultivated varieties. Therefore, due to the aforementioned lack of proper government support, academics search for alternatives to contribute to the database for the development and improvement of descriptors (Flôres Jr, 2015).

Plant breeding integrates classical and molecular techniques in order to achieve a more substantial relative increase in efficiency and higher genetic gains in crops that are of economic interest. Therefore, a complementary alternative to morphological characterization is the use of molecular markers, which intend to detect genome variation by accessing polymorphism of specific sequences of DNA (Borém and Miranda, 2013).

In order to perform molecular markers analysis, the DNA extraction process must be effective to guarantee the quality, quantity, and integrity of DNA in procedures such as Polymerase Chain Reaction (PCR), a basic technique for multiple molecular markers analysis. Moreover, it is crucial to develop low-cost protocols to meet samples demand. Since the black wattle contains phenols and tannin in its foliar structure, these compounds create an oxidized and gelatinous consistency sample, which can negatively interfere in the quality and integrity of the extracted DNA (Sahu et al., 2012). 
Therefore, the objective of this study was to refine the process of genomic DNA extraction for the black wattle, considering sample storage and adaptations in the Cetyl trimethyl ammonium bromide (CTAB) standard protocol.

\section{Material and Methods}

TANAC (http://www.tanac.com.br/) a company from Rio Grande do Sul, Brazil, provided the black wattle material, which consisted of two clones labeled A and B. These samples were chosen because they showed high productivity and rooting rates in the cloning process via cutting. Moreover, the leaflets were collected from a clonal hedge located in the forest nursery from the Laboratory of Forest Biotechnology, at the Federal University of Paraná. Each clone provided 100 to $150 \mathrm{mg}$ of fresh leaflets; this same amount was followed for the refrigerated samples, which were stored for seven days. The genomic DNA extraction was performed using the CTAB method (Doyle and Doyle, 1987) with some adaptations.

The first step was cell lysis, when leaflets were mechanically macerated and vegetal tissue and cells were macerated with $1 \mathrm{~mL}$ of CTAB buffer $(100 \mathrm{mM}$ Tris-Cl $8.0 \mathrm{pH} ; 1,4 \mathrm{M} \mathrm{NaCl} ; 20 \mathrm{mM}$ EDTA; $2 \%$ CTAB; $1 \%$ Polyvinylpyrrolidone; $0,2 \%$ 2-mercaptoethanol). Identified samples were transferred to microtubes, where 700 $\mu \mathrm{L}$ of CTAB were added, and samples were kept in water bath at $65^{\circ} \mathrm{C}$ for 30 minutes.

The organic extraction was performed by adding $600 \mu \mathrm{L}$ of chlorophyll (24:1, chloroform: isoamyl alcohol). The samples were homogenized and centrifuged at 28,000 RCF for five minutes and $600 \mu \mathrm{L}$ of the aqueous phase was transferred into a new microtube. From this stage onward, adaptations for the second cycle of organic extraction were performed, and the samples were separately submitted to:

1. The addition of $500 \mu \mathrm{L}$ of chlorophyll, homogenization, centrifugation at 28,000 RCF for five minutes, and $500 \mu \mathrm{L}$ of the aqueous phase was transferred into a new microtube;

2. The addition of $500 \mu \mathrm{L}$ of chlorophane (25:24:1, phenol formaldehyde: chloroform: isoamyl alcohol), homogenization, centrifugation at 28,000 RCF for five minutes and $500 \mu \mathrm{L}$ of the aqueous phase was transferred to a new microtube;

3. The addition of $5 \mu \mathrm{L}$ of proteinase $\mathrm{K}(20 \mathrm{mg} / \mathrm{mL})$ and the microtubes were kept in water bath at $60^{\circ} \mathrm{C}$ for 30 minutes.

The cleaning stage consisted of the addition of $400 \mu \mathrm{L}$ of isopropyl alcohol in microtubes that were kept refrigerated at $-18^{\circ} \mathrm{C}$ for one hour. Then, samples were centrifuged at $8,000 \mathrm{RCF}$ for three minutes and the supernatant was discarded. The pellet was washed twice with $500 \mu \mathrm{L}$ of ethanol $70 \%$ and $500 \mu \mathrm{L}$ of absolute ethanol. The pellet was then dried and resuspended in $50 \mu \mathrm{L}$ of ultrapure water.

Subsequently, half of the samples that were submitted each treatment received $1 \mu \mathrm{L}$ of RNase $(10$ $\mathrm{mg} / \mathrm{mL}$ ), and the microtubes were kept in water bath at $37^{\circ} \mathrm{C}$ for one hour. The extracted DNA was visualized through $0.8 \%$ of agarose gel electrophoresis; samples were stained with GeIRed ${ }^{\mathrm{TM}}$ and recorded under UV light. DNA diluted to $20 \mathrm{ng} / \mu \mathrm{L}$ was submitted to PCR technique using universal primers for intron region tnrL according to Taberlet et al. (2007) (Table 1).

Availability of the DNA extraction process was confirmed by amplification of about $500 \mathrm{bp}$ fragment observed by $1.5 \%$ agarose gel electrophoresis. The samples were stained with GelRed ${ }^{\mathrm{TM}}$ and gel recorded under UV light. Figure 1 consists of a diagram regarding the stages of the DNA extraction process according to the adaptations in the CTAB protocol.

Table 1. Primers used to amplify the $t n r L$ chloroplastidial region

\begin{tabular}{ccc}
\hline Primer & Sequence 5' - 3' & PCR conditions \\
\hline Forward & CGAAATCGGTAGACGCTACG & 10 min at $95^{\circ} \mathrm{C}$ \\
& & 35 cycles $-30 \mathrm{~s}$ at $95^{\circ} \mathrm{C}, 30 \mathrm{~s}$ at $50^{\circ} \mathrm{C}$ \\
\hline Reverse & GGGGATAGAGGGACTTGAAC & 2 min at $72^{\circ} \mathrm{C}$ \\
\hline
\end{tabular}

Agrarian, Dourados, v. 13, n. 49, p. 323-329, 2020. 

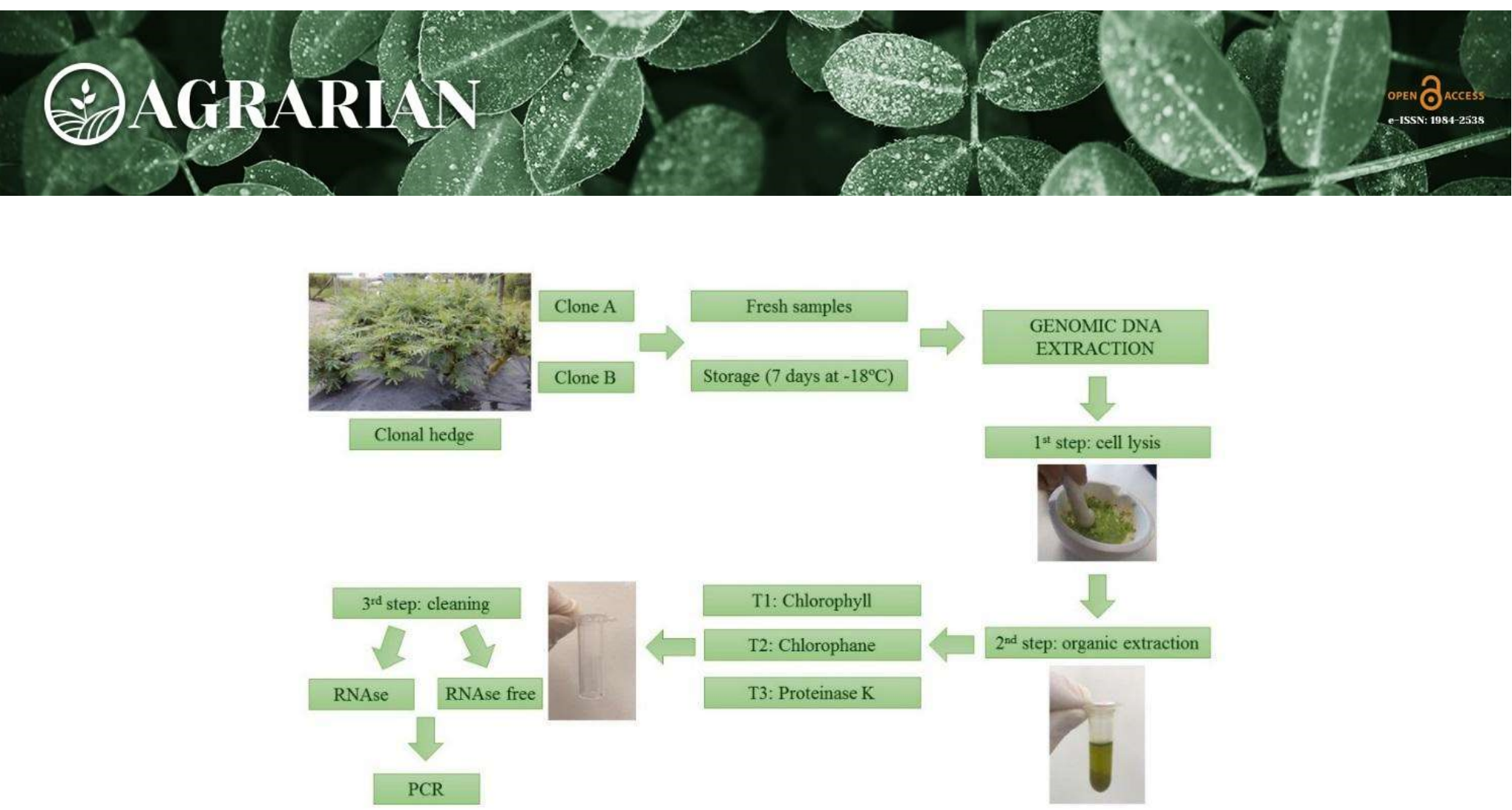

Figure 1. Diagram of stages taken during the process of genomic DNA extraction from black wattle leaflets

\section{Results and Discussion}

Generally, plant tissue is collected far from the laboratory where the DNA extraction process will be accomplished. Therefore, it is necessary to perform a method that preserves the freshness of the samples and that minimizes oxidation, which can result in the loss of quality in samples. Regarding the results, we observed that refrigeration was effective at keeping the quality of the leaflets samples. Through a visual inspection in the agarose gel obtained from the electrophoresis, we were unable to observe differences among the results of samples refrigerated with the results of the fresh samples (Figure 2).

\section{Fresh samples}

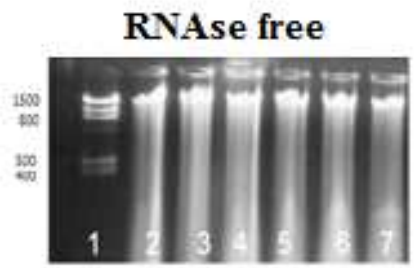

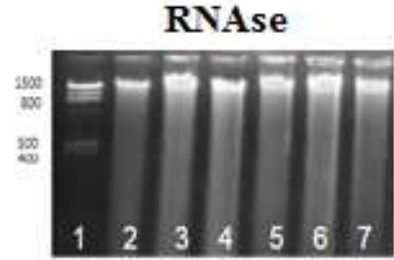

Stored samples

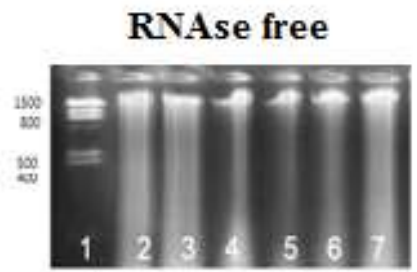

Figure 2. DNA extraction results in $0.8 \%$ agarose gel $(3 \mathrm{~V} / \mathrm{cm})$. 1. Lamba Hind III, molecular weight marker; 2 and 3. Clones $A$ and $B$ - chlorophyll extraction; 4 and 5. Clones $A$ and $B$ - chlorophane extraction; 6 and 7. Clones $\mathrm{A}$ and $\mathrm{B}$ - proteinase $\mathrm{K}$ extraction

Likewise, Aubakirova et al. (2014) did not observe influences of low temperatures in the quality of DNA extracted from fresh samples of fruit trees, stored at $-80^{\circ} \mathrm{C}$ on silica gel. Oliveira et al. (2017) observed that for Fabaceae species, samples stored at $-20^{\circ} \mathrm{C}$ showed better results than in silica gel, considering the quality and the amount of DNA extracted used in PCR process, e.g., from the trnL region. Therefore, storage of leaflets at low temperatures can be effective to optimize time for sample collection in studies of great impact. 
Our study hypothesizes that the use of different organic solvents such as chlorophyll (composed by chloroform) and chlorophane (composed by phenol formaldehyde-chloroform) denatured proteins and enzymes that affect the quality of the DNA extracted on the cell lysis phase. Adding proteinase $\mathrm{K}$ is also an alternative to remove these proteins, which facilitates in achieving purity and integrity of the DNA extracted. Besides, following the CTAB protocol enabled the extraction of nucleic acids by adding RNase to degrade RNA, and thus it is possible to obtain a cleaner DNA.

In forest species, mature tissues may hold phenolic compounds that interfere in the quality of the extracted DNA. In some cases, neither chlorophyll nor chlorophane are capable of providing a good extraction of nucleic acids, as Mazza and Bittencourt (2000) note in a study with araucaria needles. We observed that for the black wattle clones tested, both chlorophyll and chlorophane were efficient to extract DNA (Figure 2).

The same was observed when adding proteinase $\mathrm{K}$, which enabled DNA extraction but did not improve its quality. Proteinase $\mathrm{K}$ is associated with the digestion of proteins linked to the DNA molecule, but it cannot be efficient when added to the extraction buffer. Silva et al. (2015) extracted DNA from leaves of Eucalyptus camaldulensis Dehnh, and observed thin bands and degradation of DNA when they used a buffer with proteinase $\mathrm{K}$. Both in fresh and stored samples (clones $A$ and $B$ ) of black wattle, the efficiency of these compounds for DNA extraction was verified.

In addition to other components like polysaccharides, proteins, and phenolic compounds, RNA also affects the DNA quality. Thereby, adding RNase is an alternative to obtain DNA free from RNA molecules in protocols for plant cells DNA extraction (Capeloto et al., 2005). According to Romano and Brasileiro (1999), adding RNase in DNA samples is an optional step, but it helps to improve samples regarding their purity. For black wattle clones, the authors observed that the use of RNase is more efficient to clean the extracted DNA, regardless whether the samples are fresh or whether they were refrigerated for seven days (Figure 2).

To validate the availability of extracted DNA, samples were submitted to the PCR procedure to amplify the chloroplast $t n r L$ intron, studied in a taxonomic investigation for phylogenetic reconstruction and identification of different species of plants (Taberlet et al., 2007). The primers used are considered universal (Table 1) and, therefore, enabled the amplification of the DNA extracted from black wattle because it yielded a sufficient quantity and quality for the PCR procedure.

Cury et al. (2005) found that, during the PCR process, large amounts of DNA could enable bindings between DNA template strands, in addition to primer annealing, which results in non-specific conformation of products. Thus, the amount of DNA may interfere in the purity of the template and affect the amplification quality. In Figure 3, we observe the result of the amplified fragment of $t n r \mathrm{~L}$ intron, showing that although the amplification quality of the extracted DNA was not satisfactory, it was good enough to amplify this region through the PCR process.

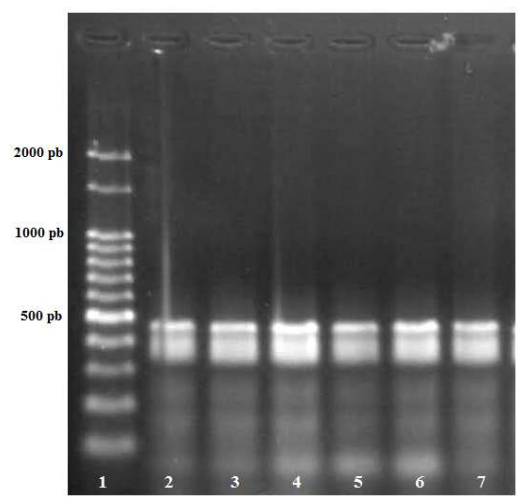

Figure 3. PCR products of trnL region in $1.5 \%$ agarose gel $(3 \mathrm{~V} / \mathrm{cm})$. 1 . Ladder $1 \mathrm{~Kb}$, molecular weight marker; 2 and 3. Clones $A$ and $B$ - chlorophyll extraction; 4 and 5. Clones $A$ and $B$ - chlorophane extraction; 6 and 7. Clones $\mathrm{A}$ and $\mathrm{B}$ - proteinase $\mathrm{K}$ extraction 


\section{Conclusions}

Concerning the adaptations in the CTAB protocol for genomic DNA extraction from samples of two clones of black wattle (Acacia mearnsii De Wild.), we observed that chloroform, phenol formaldehyde and proteinase $\mathrm{K}$ are efficient compounds to obtain an adequate DNA via the PCR amplification process. Therefore, we suggest the use of chlorophyll due to its lower costs. Also, we suggest the use of RNase to obtain cleaner DNA, and this can be applied to either fresh or stored samples.

\section{Acknowledgment}

We thank MAPA (Ministério da Agricultura, Pecuária e Abastecimento) and CNPq (Conselho Nacional de Desenvolvimento Científico e Tecnológico) for the financial support and to TANAC for providing the black wattle materials in the development of this study. The authors would also like to thank the Academic Publishing Advisory Center (Centro de Assessoria de Publicação Acadêmica, CAPA - www.capa.ufpr.br) of the Federal University of Paraná for assistance with English language editing.

\section{References}

AGEFLOR: ASSOCIAÇÃO GAÚCHA DE EMPRESAS FLORESTAIS. A indústria de base florestal no Rio Grande do Sul 2017: ano base 2016. Porto Alegre: AGEFLOR, 2017, 13p.

AUBAKIROVA, K.; OMASHEVA, M.; RYABUSHKINA, N.; TAZHIBAEV, T.; KAMPITOVA, G.; GALIAKPAROV, N. Evaluation of five protocols for DNA extraction from leaves of Malus sieversii, Vitis vinifera, and Armeniaca vulgaris. Genetics and Molecular Research, v.13, n.1, p.1278-1287, 2014.

BORÉM, A.; MIRANDA, G. V. Melhoramento de plantas. 6. ed.. Viçosa: UFV, 2013. 523p.

CAPELOTO, A.; UNÊDA-TREVISOLI, S. H.; ARRIEL, N. H. C.; QUEIROZ, M. A.; DI MAURO, A. O. Qualiquantitative analysis of genomic DNA extraction methods in watermelon. Revista Ceres, v.52, n.299, p.1-12, 2005.

CURY, P. R.; FURUSE, C.; ARAÚJO, N. S. Technique and application of polimerase chain reaction in dentristy. Revista Odontológica de Araçatuba, v.26, n.2, p. 34-39, 2005.

DOYLE, J. J.; DOYLE, J. L. A rapid DNA isolation procedure for small quantities of fresh leaf tissue. Phytochemical Bulletin, v.19, p.11-15, 1987.

FLÔRES JR, P. C. Caracterização morfológica e análise de divergência genética entre clones de acácianegra (Acacia mearnsii De Wildeman). 2015. Ano de obtenção: 2015. 76 f. Dissertação (Mestrado em Engenharia Florestal) - Universidade Federal do Paraná, 2015.

IBÁ: INDÚSTRIA BRASILEIRA DE ÁRVORES. Relatório IBÁ 2016 ano base 2015. Brasília: IBÁ, 2016, 100p. MAZZA, J. C. M.; BITTENCOURT, J. V. M. Extraction of DNA from plant tissue of Araucaria angustifolia (Araucariaceae). Boletim de Pesquisa Florestal, n.4, p.12-17, 2000.

OLIVEIRA, L. C.; RODRIGUES, D. P.; HOPKINS, M. J. G. Comparison of six DNA extraction protocols to molecular analysis in species of Fabaceae. Scientia Amazonia, v.6, n.3, p.38-45, 2017.

ROMANO, E.; BRASILEIRO, A. C. M. Extração de DNA de plantas. Biotecnologia, v.2, n.9, p.40-43, 1999.

SAHU, S. K.; THANGARAJ, M.; KATHIRESAN, K. DNA Extraction protocol for plants with high levels of secondary metabolites and polysaccharides without using liquid nitrogen and phenol. ISRN Molecular Biology, v.2012, p.1-6, 2012. 
